\title{
Comentario Bibliográfico
}

FORMAR DOCENTES. Cómo, cuándo y en qué condiciones aprende el profesorado. Christopher Day. Narcea S.A. Ediciones, 2005. Madrid, España.

Para la sociedad en general y, particularmente, para quienes se ocupan de los problemas educativos y se dedican a la labor docente o, en el mejor de los casos, a la formación de profesores, esta labor siempre amerita múltiples reflexiones y nuevas miradas que dinamicen, pongan en la actualidad y en debate el quehacer docente.

En la obra referencia, el profesor Day retoma diversidad de aspectos relacionados con la formación de docentes con base en los resultados de múltiples investigaciones adelantadas por más de 20 años. La obra se divide en 10 capítulos en donde se abordan diversidad de temas, entre los que se destacan: el ser docente y el desarrollo profesional; los docentes como investigadores; experiencia, maestría y competencia para comprender el desarrollo docente; condiciones de trabajo de los docentes -aulas, culturas y liderazgo-; evaluación, cambio y planificación del desarrollo personal; el papel de los docentes en la sociedad del conocimiento, entre otros.

Según el propio autor, "este libro presenta una visión holística del desarrollo profesional continuo de los docentes, de los retos y limitaciones que afectan su capacidad de mantener el compromiso y de hacerse más competentes, de manera que puedan elevar la educación y el rendimiento de los niños y jóvenes cuyo aprendizaje se les ha confiado" (Pág.13)

Quizás, algunos de los planteamientos del autor en la obra no resultan novedosos, pues para quienes se dedican a la formación de docentes existe ya, desde hace varios años, cierta tradición en los temas que se abordan; no obstante, siempre resulta interesante reflexionar y re-examinar diversos aspectos de la formación docente que se creen superados, pero que ameritan profundas reflexiones, como es la propia motivación de los profesores por aprender, transformar y mejorar su labor.

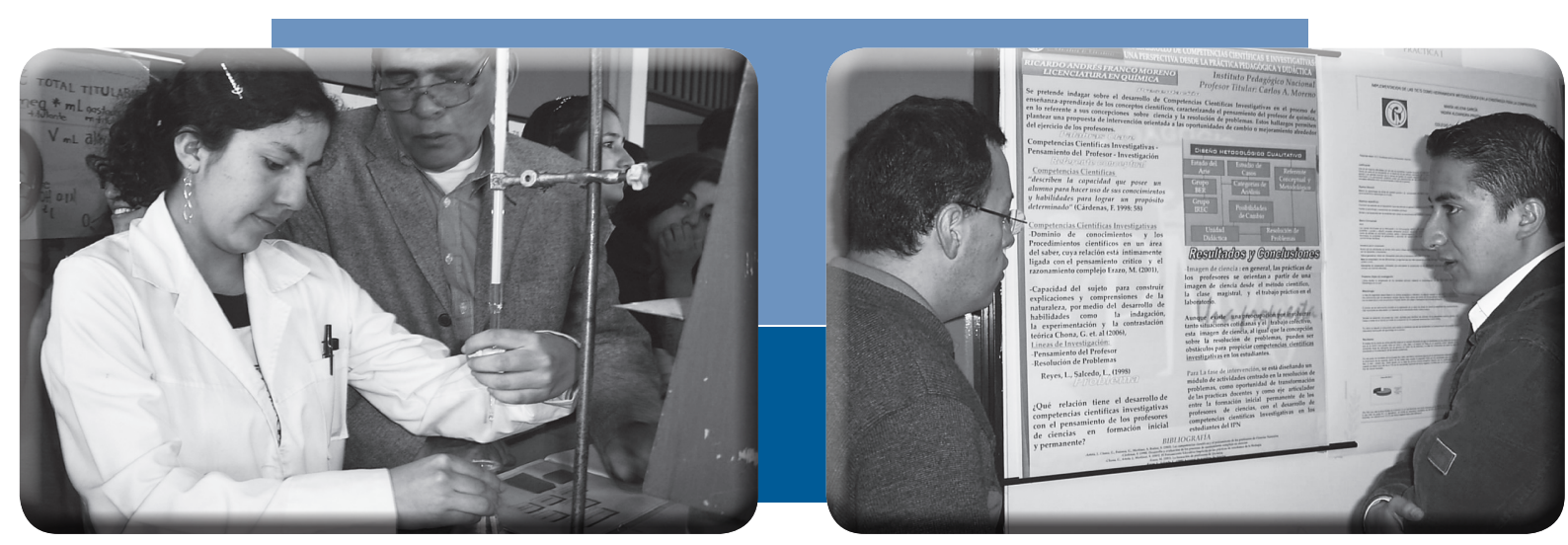

